Journal Home Page:

http://perlinguam.journals.ac.za

\section{Per ${ }_{\text {Linguam }}$}

A Journal for Language Learning Tydskrif vir Taalaanleer

\title{
THE CURRENT POLITICS OF AFRICAN LANGUAGES IN ZIMBABWE
}

\author{
Maxwell Kadenge \\ University of the Witwatersrand \\ Victor Mugari \\ University of Zimbabwe
}

The Zimbabwean sociolinguistic situation has for long been dogged by the lack of a holistic and well-articulated language policy. This situation is not peculiar to Zimbabwe, but common throughout Africa. This article examines the implications and complications of the new constitutionally enshrined national language policy in Zimbabwe. To a larger extent, the new policy is a result of protracted activism by minority ethno-linguistic communities in Zimbabwe. However, the shift from recognising three official languages to sixteen would be an end itself if stakeholders do not proactively engage with the policy and develop effective strategies for successful implementation. Adequate financial resources, political will and stakeholder buy-in are needed for the successful implementation of this policy. This article maps the way forward for Zimbabwe's language policy and planning efforts.

\section{Keywords}

Language policy, language planning, constitution, minority languages, linguistic rights, official language

\section{INTRODUCTION}

Previous studies have argued that there has not been any meaningful language policy and planning in Zimbabwe (see, for example, Mkanganwi, 1992; Chimhundu, 1992, 1993; Viriri, 2003; Ndhlovu, 2009; Kadenge and Nkomo, 2011a, 2011b; Ndlovu, 2013). The point has been made that Zimbabwe's language situation is largely a colonial inheritance. Attempts to define the language position of the country have over the years been punctuated by policy positions orchestrated mainly by regional efforts. Of note are the Pan African Seminar on the Problems and Prospects of the Use of African National Languages of 1996 and the Intergovernmental Conference on Language Policies in Africa of 1997. The general aims of these initiatives were to design strategies for promoting the use of African languages which were deemed to be at the mercy of former colonial languages.

Zimbabwe does not have a documented national language policy to which reference may be made. The language policy is usually inferred from the language practices that characterise various spheres of life (Kadenge and Nkomo, 2011a, 2011b). This is not unusual, as Bamgbose $(1991,2003)$ has established that the unavailability of a written language policy does not mean 
that there is no policy. Rather, some policies are characterised by 'avoidance' or 'declaration without implementation' (Bamgbose, 2003: 419). As such, language policy is quite often covert and can only be inferred from observed practices (Kadenge and Nkomo, 2011b). Nevertheless, whether overt or covert, 'language policy is ever present' (Bamgbose, 2003: 149). In fact, 'the real language policy of a political and social entity should be observed not merely through declared policy statements but rather through a variety of devices that are used to perpetuate language practices, often in covert and implicit ways' (Shohamy, 2006: 46; Kadenge, 2015).

Typically, the focus of language policy research has been on the nature of policies that African governments (colonial and post-colonial) pursued in regard to the role English and African languages play in relation to their current national status and education (see, for example, Chimhundu, 1993; Hadebe 1998; Viriri, 2003; Makoni and Mashiri 2006; Makoni, Makoni and Mashiri, 2007). This state of affairs is also corroborated by Mkanganwi (1992) and Kadenge and Nkomo (2011a) who observe that most of the literature on language policy and planning that was published in the colonial and, to some extent, the post-colonial era in Zimbabwe emphasises the imposition of English on indigenous languages.

The status of most indigenous languages of Zimbabwe has imminently changed, owing to the Constitution of Zimbabwe Amendment (No. 20) Act of 2013. The Act took the radical step of acknowledging and recognising 16 languages as official languages. This constitutional pronouncement joins about 125 of the world's constitutions that, as Spolsky (2004: 11-12) notes, 'express some policy about language, and about 100 of them name one or more official languages with special privileges of use'. Before this, Zimbabwe's constitution was largely silent on language issues. In fact, Maseko and Ndlovu (2013: 153) aver that 'most indigenous languages were grouped under the minority languages cluster, with the exception of Shona and Ndebele which were hitherto assigned the status of national languages' and English as the sole official language, of course.

\section{LANGUAGE POLICY AND PLANNING}

Language policy and language planning are inseparable. Both language policy and planning are language management instruments, defined by Spolsky (2004: 11) as 'the formulation and proclamation of an explicit plan or policy, usually but not necessarily written in a formal document, about language use'. According to Shohamy (2006: 45), 'language policy (LP) is the primary mechanism for organizing, managing and manipulating language behaviors as it consists of decisions made about languages and their uses in society'. It is through language policy that decisions are made with regard to the preferred languages that should be legitimised, used, learned and taught in terms of where, when and in which contexts. Language policy is generally construed as a declaration about language use and status within a country or institutions such as universities. More precisely, a language policy can also be looked at as an official decision made by the government or responsible authority concerning the use, status and promotion of language(s). It contains decisions, rules, regulations and guidelines on the status and use of languages. Ultimately, language policies are political decisions that can only be pronounced by governments (UNESCO, 1997). A language policy, as articulated by Spolsky (2004: 11), may take for instance, 'the form of a clause in a constitution, or a language law, or a cabinet document, or an administrative regulation'. Laws are especially powerful mechanisms for 
affecting language practices, as they are supported by penalties and sanctions and can therefore ensure that policies are carried out and turn from ideologies into practice (Shohamy, 2006). The view that language policies are instruments of social control and political activity is given credence by the close involvement of government and other influential stakeholders in the shaping of language use and status (Ricento, 2006; Tollefson, 2002; Masoke-Kadenge and Kadenge, 2013). Others, such as Kamwangamalu (2001), note that language policies are transitional tools that facilitate the move from old language functions that need to be discarded to new language functions that are aspired.

Language planning is defined by Haugen (1989: 29) as 'the activity of preparing a normative orthography, grammar, and dictionary for the guidance of writers and speakers in a nonhomogeneous speech community'. In most instances, language planning is usually a response to language policy. That is, the type of planning has to march in step with the goals spelt out in the policy. Status planning is responsible for prescribing official and national languages. Such prescription may occur before or after a policy declaration. For corpus planning purposes, there is need to purify, standardise, unify and modernise terminology and any other such goals. In acquisition planning, however, the focus is on increasing the number of speakers, possibly for national imperatives set in the relevant documents as unity and education. Zimbabwe as a multilingual and multicultural society with a long history of language contact through trade and colonisation is not immune from the need to have a functional language policy. This article is, therefore, intended as a small but significant empirical contribution to the current language policy and planning debate in Zimbabwe in particular and Africa as a whole.

\section{THE HISTORY OF THE LANGUAGE QUESTION IN ZIMBABWE}

As intimated in the introduction, the state of language policy and planning in Zimbabwe, like many African countries, has been influenced by colonial history (Hungwe, 2007; Chabata 2008; Ndhlovu, 2009). Due to factors such as history and politics, indigenous languages 'remain in the shadows of the various "colonial", "official" languages' (Maseko and Ndlovu, 2013: 151). By extension, the colonial language situation in Zimbabwe is well-documented (see for example, Chimhundu, 1993; Hadebe, 1998; Magwa, 2006; Mutasa and Ogutu, 2008; Ndhlovu, 2009; Ndlovu, 2013). By contrast, specific developments that have occurred after Zimbabwe gained its independence, spanning from 1980 to present day, are sparsely treated. This article seeks to contribute to filling this lacuna. For instance, the question of what the self-governing era introduced and promoted as far as language is concerned is still open. We review the postindependence language policy in Zimbabwe, bearing in mind that general characteristics of African language policies are notorious for 'avoidance, vagueness, arbitrariness, fluctuation and declaration without implementation' (Bamgbose, 1991: 11). In any case, most of the recommendations that are made to solve language problems are never implemented for the benefit and advancement of indigenous languages (Nhongo, 2013: 1210). One result is that policies remain as declarations of intent that have little functional use beyond political symbolism. The Zimbabwean government, on its own part, prefer to do nothing to promote or develop African languages (Chimhundu, 1992). If a government does nothing about the language question, normally there are no expectations for it to implement any language-related policy. There is, thus, no accountability. 
Ndhlovu (2009: 130) cites a number of documents that he believes are reflective of the country's national language policy and language planning strategies. These are:

- The 1987 Education Act (Section 55 of Part XI);

- The Cultural Policy of Zimbabwe;

- The Position Paper on Zimbabwe's Language Policy;

- The National Language Policy Advisory Panel report (hereafter referred to as NLPAP);

- The Nziramasanga Report on Education and Training in Zimbabwe, 1999;

The following documents also embody Zimbabwe's national language policy:

- Ministry of Education and Culture report of 1990 on the 'Teaching and learning of minority languages in Zimbabwe';

- Ministry of Education Circular Number 1 of 2002 on 'Policy regarding teaching and learning';

- Ministry of Education Circular Number 3 of 2002 on 'Curriculum policy: primary and secondary schools';

- Director's Circular Number 26 of 2007 on 'Policy guidelines on the teaching of local languages in primary and secondary schools in Zimbabwe';

- Ministry of Education, Sports, Arts and Culture Quality Assurance Division Language Policy.

Kadenge and Nkomo (2011b) put these documents into two main categories. On the one hand are documents which reflect the country's national language policy on which prevailing language practices in education, media, law, administration, sports and business are predicated. On the other hand are documents that reflect the desired policy by advocating changes to the policy.

The linguistic landscape and language practices in Zimbabwe reflect a hierarchical policy. English was placed at the pinnacle of languages, functioning as the sole official language. Shona and Ndebele, on the other hand, were privileged as national languages. One could be misled by politics to think that the government sees Shona and Ndebele on par (Hachipola, 1998: xxi). Chitiga (1995), Hachipola (1998) and Mushunje (2001), for example, condemn the diglossic situation in Zimbabwe whereby English takes the most prominent position in people's lives. Shona comes in the second place followed in the third position by Ndebele. The rest, such as Kalanga, Nambya, Sotho, Sena, Shangani, Tonga, among several others, were regarded as minority or community languages (Thondhlana, 2000; Ndhlovu, 2013). It is no surprise that policy documents that have been produced to inform the formulation of a national language policy, such as the Cultural Policy of Zimbabwe (Government of Zimbabwe, 1999), the Position Paper on Zimbabwe's Language Policy (Government of Zimbabwe, 1997), the National Language Policy Advisory Panel (Government of Zimbabwe, 1998) report, and the Nziramasanga Commission Report on Education and Training (Nziramasanga, 1999), have criticised the language practices in education and other public sectors for entrenching the dominance of English (Kadenge and Nkomo, 2011a).

While Zimbabwe may not have had a meaningful post-independence language policy, it did have a language-in-education policy based on Section 62 of the Education Act of 1987 (Chapter 25: 4) 
(Government of Zimbabwe 1987) revised in 2006. The first three provisions of the Education Act pertain directly to the role of English in Zimbabwean education. They stipulate that:

1. Subject to this section, the three main languages of this country, namely, Shona, Ndebele and English, shall be taught in all primary schools from the first grade as follows.

a. Shona and English in all areas where the mother tongue of the majority of the residents is Shona; or

b. Ndebele and English in all areas where the mother tongue of the majority of the residents is Ndebele.

2. Prior to the fourth grade, either of the two languages referred to in paragraph (a) or (b) of subsection (1) may be used as the medium of instruction, depending upon which language is more commonly spoken and understood better by the pupils.

3. From the fourth grade, English shall be the medium of instruction provided that Shona and/or Ndebele shall be taught as subjects on an equal-time-allocation basis as the English language.

The above stipulations do not refer to English in isolation but together with the other indigenous languages. Nevertheless, they have been rightfully interpreted as responsible for English hegemony in the country's education system and society at large. The stipulations make English a school subject throughout the education system, entrench it as the medium of instruction from the fourth grade upwards and position it as a barometer of educational achievement (Kadenge and Nkomo, 2011a). It has also been observed that practices in schools are such that English is even more dominant than is designated in the policy (see, for example, Mlambo, 2009). Shona, Ndebele and English are referred therein as main languages whose education is accessible from first grade even in areas where they are not first languages. In fact, Shona and Ndebele operate as languages of instruction up to third grade, after which English takes over (Government of Zimbabwe, 1987). The same statute empowers the Minister responsible for education to authorise the teaching of minority languages to third grade in areas where they are predominantly spoken before they shift to either Shona or Ndebele. Such minority languages are Tonga, Venda, Sotho, Kalanga, Shangani, and Nambya. However, in 2011, Tonga became the first minority language in the history of independent Zimbabwe to be examined at seventh grade (Maseko and Moyo, 2013).

The language-in-education Act predictably sparked controversy. One of its most obvious results was an increase in language activism, with associations representing minority languages becoming more vocal and active. The bone of contention, was, as Nyika (2008: 6) puts it, that their languages were not being taught in schools to any significant level, and that this constituted discrimination on the grounds of ethnicity and language. Such concerns were justified, in light of the 2005 UNESCO Convention which strongly recommended embracing linguistic diversity and multilingualism, particularly taking the mother tongue as the primary communicative mode that unlocks an individual's potential for normal human cognitive development. 


\section{ANALYSIS AND DISCUSSION}

The discussion presented in this article is primarily based on sections pertaining to language in the Constitution of Zimbabwe Amendment Number 20 of 2013, namely, Chapter 1(6) and Chapter 4(63).

Chapter 1(6) stipulates that:

(1) The following languages, namely Chewa, Chibarwe, English, Kalanga, Koisan, Nambya, Ndau, Ndebele, Shangani, Shona, sign language, Sotho, Tonga, Tswana, Venda and Xhosa, are officially recognised languages of Zimbabwe.

(2) An Act of Parliament may prescribe other languages as officially recognised languages and may prescribe languages of record.

(3) The State and all institutions and agencies of government at every level

must-

(a) ensure that all officially recognised languages are treated equitably; and

(b) take into account the language preferences of people affected by government measures or communications.

(4) The State must promote and advance the use of all languages used in Zimbabwe, including sign language, and must create conditions for the development of these languages.

Chapter 4(63): Language and culture, says:

Every person has the right-

(a) to use the language of their choice; and

(b) to participate in the cultural life of their choice; but no person excising these rights may do so in a way that is inconsistent with this chapter.

This article examines these constitutional provisions in light of current policy, planning and language practices in Zimbabwe.

\section{POLICY}

It is our observation that, first, the official recognition of sixteen languages by the government of Zimbabwe is not accompanied by modalities, methodologies and rationale used to come up with the list of languages. Ndau, for example, is structurally a dialect of Shona, along with other varieties like Karanga, Zezuru, Korekore and Manyika (Doke, 1931). Why, then, has Ndau been singled out as a separate language but not the other dialects of Shona? These distinctions needed to be spelt out clearly and rigorously justified. Secondly, owing to the diglossic nature of the Zimbabwean speech community, the domains where these languages should/can be used are conspicuously silent. Without a clearly articulated language-in-education policy in which these 
newly recognised languages have an adequately characterised point of engagement and model of support coupled with a sound implementation agenda, the implementation of the whole policy becomes unfeasible.

Thirdly, our interpretation of Section 6 of Chapter 1 suggests that the official recognition of sixteen languages is contradictory. Section 6:2 states that, 'An Act of Parliament may prescribe other languages as officially recognised languages and may prescribe languages of record'. This section, as far as it aims to designate domains of use among the recognised languages, is praiseworthy. However, this aim is directly contradicted by the succeeding Section 6:3a, which recommends that 'The State and all institutions and agencies of government at every level must ensure that all languages are equitable'. Selecting some languages as languages of record does not create a level field amongst the officially recognised languages. Instead, those selected stand to gain a higher sociolinguistic status triggered by the esteemed function, leaving the other languages - in this case those of minority status - to the periphery. It is highly likely that all minority status languages that were not recognised as official or national languages - and were therefore relatively less standardised - before the new dispensation will stay that way. Thus, Shohamy (2006: 61) insightfully observes that 'as is often the case, the mere act of declaring certain languages as official does not carry with it much meaning in terms of actual practice in all domains and it does not guarantee that officiality will be practiced. It often remains at the level of "declaration" even if the officiality is anchored in law'. Speakers of all official languages expect them to be used for official communication in private and public institutions including education, courts, media, sports, hospitals and prisons, among many others.

A cursory study of the official languages inventory in the current Zimbabwean Constitution shows that there is no easy fix to certain soft issues to do with perceptions and attitudes towards some of the recently recognised official languages. First, the language identified as 'sign language' is conspicuously written with lower case, portraying an image that it cannot be treated in the same way as its oral counterparts. The initial letters of all oral languages are capitalised. The interpretation or inference would be that those responsible for penning this document were not convinced that Zimbabwe Sign Language is a surviving language just like any other variety they had listed.

Lacking from the treatment of the language is also the notion of speech community or ethnic identification. For instance, all the other indigenous languages have clearly encrypted ethnic or regional identities inscribed within their names. Venda is spoken by the Venda people, Tonga by the Tonga, Ndau by the Ndau, Sotho by the Sotho, etc. Sign Language, however, has been generalised, probably as an international variety, erroneously assuming that it is universally homogeneous and therefore immune to variation. Like the oral languages, Sign Language has regional and international variations, which, depending on the country, have different standardisation levels. In most cases, its international variations are mutually unintelligible suggesting that they are different language varieties altogether. The standard practice would have been to name it as Zimbabwean Sign Language (henceforth ZSL) in similar fashion to American Sign language (ASL), South African Sign Language (SASL) (Reagan, 2007), Kenyan Sign Language (KSL), Tanzanian Sign Language (TSL), British Sign Language (BSL) (Jefwa, 2009:162) and Australian Sign Language, etc. The users of ZSL are normally resident within Zimbabwe and are therefore influenced by Zimbabwean culture. ZSL is the natural language of 
Zimbabwean Deaf people which is sometimes used by their hearing parents, off-springs and teachers. It is a complete and legitimate language whose grammar and vocabulary are independent of any other language spoken in Zimbabwe. Its visual-gestural units of communication are independent of these spoken languages. Consequently, there is no Shona Sign Language, Ndebele Sign Language etc. ZSL is one of the many, different and mutually unintelligible Sign Languages of the world which, as Akach (1997) says, share some features and signs although there is no universal Sign Language. ZSL (ZimSign, Coltart, 2011) has a number of varieties or regional variations (Coltart, 2011: iv; Miti, 2011: v), and some standard national dictionaries notably Chimedza (1998) and Mhlanga, (2011). In fact, ZSL is a normal candidate for Universal Grammar (UG), with universal language features such as arbitrariness, creativity, instinctive acquisition, etc. and all sociolinguistic aspects such as dialectology and general constraints governing language use. In line with the above arguments, we propose that the name be captured as ZSL as this is in tandem with the Universal Declaration on Linguistic Rights which considers the right to a language community on the basis of historicity, territoriality and self-identification as a people (UNESCO, 1996: 4).

Fourthly, the language recognised as Koisan is elsewhere identified as a language family, comparable to other families such as Bantu. Koisan language (also spelt Khoisan, Khoesan) speakers are spread across Southern Africa in countries such as Angola, Botswana, Namibia, South Africa, Zimbabwe and Zambia, and according to Colclough and McCarthy (1980: 7), 'they are the earliest group of people to inhabit parts of Southern Africa'. The Koisan are also referred to as 'Bushman', though the term has become unpopular due to its derogatory nature (see, for example, Raper, 2009). Koisan languages such as Kua, Shua, Tshwa, Gwi, Gana and Hua, etc. are concentrated in Botswana (Batibo, 2005: 70). Elsewhere, as Mafela (2009: 231) notes, 'the Penduka Declaration on the Standardization of Ju and Khoe languages challenged the use of the referent label Khoesan, noting that each language family has different and unrelated grammars, word orders and vocabulary (WIMSA, 2001: 2)'.

There is also controversy associated with the compound treatment of the term Koisan itself. Among the groups classified as speakers of the language, the San group is actually an autonomous linguistic variety with a divergent structure from that of Khoe, as such, its speakers feel belittled when their language is treated under the Koisan label. Compounding this desperate situation is the view that the term Koisan inherently suppresses the San people's right to selfdetermination and autonomy as observed in the Penduka Declaration (WIMSA, 2001: Appendix 3) The language is written with a small letter 's' in the compound name, against the standard procedure befitting other languages. The use of the term in the Zimbabwean constitution is therefore oblivious to the raised issues. More so, Chimhundu (2005) notes that Tshwawo, a Koisan language, is the only non-Bantu African language spoken in Zimbabwe, so, naming it as such in the constitution would only be fair to the community.

In Zimbabwe, there are ongoing efforts to rescue the Tshwawo language, which is on the verge of extinction. It is spoken in the Tsholotsho district of the Matabeleland North Province of Zimbabwe. The language was reported to have had 14 fluent native speakers at the beginning of year 2014, all of whom were in their advanced ages, by the time of writing, they had been reduced to 12. The African Languages Research Institute (ALRI) situated at the University of Zimbabwe is spearheading a maintenance project aimed at creating an orthography and to 
document the language for the benefit of approximately 2000 non-fluent speakers and for the heritage of the country. However, if the goal to document this highly threatened language is to be achieved before the fluent generation is lost, there is need for concerted efforts by other stakeholders, which include academics, government, NGOs and the Tshwawo community itself. The stakeholders need to walk the talk, so to speak, and break the declaration without implementation cycle that has inadvertently become the norm.

\section{PLANNING}

The development of the 2013 Constitution of the Republic of Zimbabwe Number 20 in which 16 languages are recognised as official, is socio-politically speaking, quite an achievement. Precisely, it is both a cause for optimism and a respectable starting point. However, optimism and starting point are not enough. There is need to proactively embark on an all-encompassing approach to planning that involves all stakeholders that would consummate in the implementation of the policy. As already noted, deliverables have always been the blind-spot plaguing language planning in Zimbabwe. Added to this, is the need for comprehensive and genuine consultation of, and buy-in by, all stakeholders. Experience suggests that it would be a mistake if some stakeholders are bypassed, whether by design or mistake.

Our recommendations are predicated on the conviction that the Zimbabwean language policy, if it is to enjoy non-refutable legal basis and gain maximally sound (socio) linguistic traction that ensures its feasibility during implementation, needs to be overtly well-articulated. The template for achieving this involves the selection of a competent implementation team comprising linguists (theoretical and applied), educationists, language rights experts and activists, politicians, community leaders and social workers. This implementation team should develop an effective, time-bound, feasible and workable plan for the implementation of this policy. Such a plan should be accompanied by appropriate infrastructure for managing and monitoring the implementation of this policy. A pilot programme may be necessary to test the feasibility of the project's terms of reference.

Language rights enshrined in Section 3:1a of Chapter 1 cited and Section 63a of Chapter 4 which states that, 'Every person has the right to use the language of their choice', need to be systematically observed. It constitutes a serious breach of human and constitutional rights to linguistically exclude some sections of the populace from central and critical national programmes. For instance, the singing of the national anthem is limited to the two previously designated official national languages, Shona and Ndebele. As yet, there is no indication that the situation would be changed to incorporate the other 14 officially recognised languages. At present the new constitution is available in three languages - English, Shona and Ndebele and we hope that it will be translated into the other 14 official languages.

The petition to the Parliament of Zimbabwe by the Deaf Youths in Zimbabwe (Deaf Zimbabwe Trust, 2014) is testimony that there is serious need for systematic, proper and rigorous language planning. The petition reflects lack of tangible progress regarding the implementation of the constitutional provisions on Sign Language. The grievances are, inter alia, that there are no teachers who are proficient in Sign Language and teacher training curriculum does not offer such training, and there are inadequate interpretation facilities on national broadcasting stations. The 
Deaf Youths in Zimbabwe (Deaf Zimbabwe Trust, 2014) petitions for the realignment of the Education Act with the new constitution and to introduce Sign Language training at teacher training institutions, are in line with the government's position on supporting inclusive education.

Policy implementation is affected significantly by the extent to which resources are committed to the policy (Masoke-Kadenge and Kadenge, 2013). One of the excuses that the government of Zimbabwe has given for not promoting and developing indigenous languages has been lack of financial resources. Financial resources are an important means by which implementers are enabled to initiate, promote and manage the implementation of a policy. Fishman (1987) rightly notes that there is no serious language planning without a budget. Likewise, Madiba (2010: 331) argues, 'allocation of resources is critical for any successful language policy implementation'. It is noteworthy that the provision of resources distinguishes between language policy implementation and mere window dressing (Masoke-Kadenge and Kadenge, 2013).

Elsewhere, poor and unimpressive results have been reported after efforts had been made to empower indigenous languages through enhancing their status and extending their domains of use (Bamgbose, 2011: 1). Spolsky (2004: 11) corroborates this by noting that 'even the existence of such an explicit policy does not guarantee that it will be implemented, nor does implementation guarantee success'. In most instances, the officialised colonial languages, because of the diglossic nature of the societies, retain their dominance as they are languages of higher status used in prestigious domains. The success to the planning and implementation of the constitutional mandate on language relies on reviewing these previous attempts effected elsewhere and build on their strongest points, attempting along the way to rewrite the colonial policies from planning through language-in-education policy to dealing with attitudes and community involvement.

\section{CONCLUSION}

This article has attempted to unpack the implications and complications of recent constitutional changes in Zimbabwe on language policy and planning. It was noted that Zimbabwe has for a long time been dogged by a lack of a holistic, well-articulated and documented language policy. That could all change. For change to happen, however, declarations need to be accompanied by deliverables. The article noted the need to amend or standardise the constitutional clause on language especially with regards to Sign Language and Koisan. It was also evident in the discussion that the language-in-education policy needs to be remodeled to reflect the constitutional changes. This article also highlighted the lack of clearly spelt out domains of use of the officialised languages and, therefore suggests that such domains need to be clearly laid out since the society is polyglossic. Without laid-down domains, some languages would continue to be overshadowed by the stronger ones, inadvertently creating internal colonialism and failing to avoid language death. On a planning perspective, the languages have already been given official status, so there is need for stakeholders to embark on corpus planning in a bid to smoothen implementation. Most of the languages that have been officialised have very low degrees of standardisation as compared to others like Shona and Ndebele, so they would require dictionaries, grammar books, literature and even orthographies. Adequate financial resources, political will and stakeholder buy-in are needed for successful policy implementation. We 
recommend that the government walk the talk of implementation. More research, along rigorous quantitative and qualitative lines, would be needed to map out the implementation trajectory.

\section{REFERENCES}

AKACH, P. 1997. The grammar of sign language. Language Matters: Studies in the Languages of Africa, 28(1): 7-35.

BAMGBOSE, A. 1991. Language and the nation: The language question in Sub-saharan Africa. Edinburg: Edinburg Press.

BAMGBOSE, A. 2003. A recurring decimal: English in language policy and planning. World Englishes, 22(4): 419-431.

BAMGBOSE, A. 2011. African languages today: the challenge of and prospects for empowerment under globalization. In Bokamba, EG (ed.) Selected Proceedings of the $40^{\text {th }}$ Annual Conference on African Linguistics. Somerville, MA: Cascadilla Proceedings Project. 1-14.

BATIBO, HM. 2005. Language decline and death in Africa: Causes, consequences and challenges. Clevedon, Buffalo, Toronto: Multilingual Matters.

CHABATA, E. 2008. Language and development: Progress and challenges in a multilingual Zimbabwe. Southern African Linguistics and Applied Language Studies, 26(1): 13-26.

CHIMEDZA, R. 1998. Zimbabwe National Sign Language dictionary volume 1. Harare: Ministry of Education Sports \& Culture.

CHIMHUNDU, H. 1992. Standard Shona: Myth and reality. In Crawhall, NT (ed.) Democratically speaking: International Perspectives Planning. Cape Town: National Language Project. 77-88.

CHIMHUNDU, H. 1993. The status of African languages in Zimbabwe. Southern Africa Political and Economic Monthly (SAPEM) (October). Harare: Literary Studies Series. 5759.

CHIMHUNDU, H. 2005. Introduction. In Doke CM The unification of Shona dialects (A photographic reprint). Harare: The ALLEX Project. 8-76.

CHITIGA, M. 1995. "Double talk": The politics of language. Zimbabwe Review 1995: 6-7.

COLCLOUGH, C \& S McCARTHY. 1980. The political economy of Botswana: A study of growth and distribution. Oxford: Oxford University Press.

COLTART, D. 2011. Foreword. In Mhlanga, SK (ed.) Zimbabwean Sign Language dictionary. Bulawayo: King George IV School and Center. iv.

CONSTITUTION OF ZIMBABWE (Amendment Number 20) 2013. Harare: Government Printers.

DEAF ZIMBABWE TRUST. 2014. Petition from the Deaf Youths in Zimbabwe. Available online at http://www.deafzimbabwetrust.org/news41.html [Accessed on 27/10/2014].

DOKE, C. 1931. A comparative study of Shona phonetics. Johannesburg: University of Witwatersrand Press.

FISHMAN, JA. 1987. Conference comments: Reflections on the current state of language planning. In Proceedings of the International Colloquium on Language Planning, ed. L. Laforge, Quebec: University of Laval: 405-428. 
GOVERNMENT OF ZIMBABWE. 1987. The Education Act (amended in 1990). Harare: Government Printers.

GOVERNMENT OF ZIMBABWE. 1997. Position Paper on Zimbabwe's Language Policy. Harare: Government Printers.

GOVERNMENT OF ZIMBABWE. 1998. Report on the Formulation of a National Language Policy. Harare: Government Printers.

GOVERNMENT OF ZIMBABWE. 1999. Cultural Policy of Zimbabwe. Harare: Government Printers.

HACHIPOLA, J. 1998. A survey of the minority languages of Zimbabwe. Harare: University of Zimbabwe Publications.

HADEBE, S. 1998. Sociolinguistic issues and human factor development. In Chivaura, V \& C.G. Mararike (Eds), The Human Factor Approach to Development in Africa. Harare: University of Zimbabwe Publications. 121-134.

HAUGEN, E. 1989. Planning for a standard language in modern Norway. Anthropological Linguistics, 1(3): 8-21.

HUNGWE, K. 2007. Language policy in Zimbabwean education: Historical antecedents and contemporary issues. Compare: A Journal of Comparative and International Education, 37(2): 135-149.

JEFWA, GJ. 2009. Structural borrowing: The case of Kenyan sign language and Kiswahili contact signing. Journal of Language, Technology \& Entrepreneurship in Africa, 1(2): 160-174.

KADENGE, M. 2015. 'Where art thou Sesotho?': Exploring the linguistic landscape of Wits University. Per Linguam, 31(1): 30-45.

KADENGE, M. \& D NKOMO. 2011a. The politics of the English language in Zimbabwe. Language Matters: Studies in the Languages of Africa, 42(2): 248-162.

KADENGE, M \& D NKOMO. 2011b. Language policy, translation and language development in Zimbabwe. Southern African Linguistics and Applied Language Studies, 29(3): 259-274.

KAMWANGAMALU, NM. 2001. The language planning situation in South Africa. Current Issues in Language Planning, 2(4): 361-445.

MADIBA, M. 2010. Towards a multilingual higher education in South Africa: The University of the Cape Town experience. The Language Learning Journal, 38(3): 327-346.

MAFELA, L. 2009. Changing livelihoods, language use and language shift amongst the Basarwa of Botswana. International Journal of Multilingualism, 6(3): 229-245.

MAGWA, W. 2006. Towards an African renaissance in language planning: A review of strategies to promote the use of indigenous languages as tools for development; the case of higher education sector in Zimbabwe. In African Languages in the $21^{\text {st }}$ Century: The Main Challenges, ed. D. E. Mutasa. Pretoria: Simba Guru Publishers: 150-179.

MAKONI, S \& P MASHIRI. 2006. Critical historiography: Does language planning in Africa need a construct of language as part of its theoretical apparatus? In Disinventing and reconstituting languages, eds. S. Makoni and A. Pennycook. Clevedon: Multilingual Matters: 62-81.

MAKONI, B, S MAKONI \& P MASHIRI. 2007. Naming practices and language planning in Zimbabwe. Current issues in Language Planning, 8(3): 437-467. 
MASEKO, B \& M MOYO. 2013. Minority language revitalization in Zimbabwe- Fundamental considerations for Tonga language in the Zambezi Valley. Online International Journal of Arts and Humanities, 2(10): 248-259.

MASEKO, B \& K NDLOVU. 2013. Indigenous languages and linguistic rights in the Zimbabwean media. Online International Journal of Arts and Humanities, 2(5): 150-156.

MASOKE-KADENGE, E \& M KADENGE. 2013. 'Declaration without implementation': An investigation into the progress made and challenges faced in implementing the Wits language policy. Language Matters: Studies in the Languages of Africa, 44(3): 33-50.

MHLANGA, SK. (ED.). 2011. Zimbabwean Sign Language dictionary. Bulawayo: King George IV School and Center.

MITI, LM. 2011. Preface. In Mhlanga, S.K. (ed.). Zimbabwean Sign Language dictionary. Bulawayo: King George IV School and Center.

MKANGANWI, KG. 1992. Language planning in Southern Africa. In Crawhall, NT (ed.) Democratically Speaking: International Perspectives on Language Planning. South Africa: National Language Project. 6-11.

MLAMBO, M. 2009. A Survey of the language situation in Zimbabwe: Is there a Zimbabwean variety of English? If so, who speaks it? English Today, 25(2): 18-24.

MUSHUNJE, E. 2001. Bilingual patterns in Harare. Masters thesis, University of Zimbabwe.

MUTASA, D \& EE OGUTU. 2008. Teaching and administering in African languages: A road map to African renaissance. Pretoria: Simba Guru Publishers.

NDHLOVU, F. 2009. The politics of language and nation building in Zimbabwe. Bern: Peter Lang.

NDLOVU, E. 2013. Mother tongue education in official minority language of Zimbabwe: A language management critique. Unpublished PhD thesis, University of the Free State.

NHONGO, R. 2013. A national language policy for Zimbabwe in the twenty-first century: Myth or reality? Journal of Language Teaching and Research, 4(6): 1208-1215.

NYIKA, N. 2008. Our languages are equally important: Struggles for the revitalization of the minority languages in Zimbabwe. Southern African Linguistics and Applied Language Studies, 26(4): 457-470.

NZIRAMASANGA, CT. 1999. Report of the presidential commission of inquiry into education and training. Harare: Government Printers.

RAPER, P. 2009. The ethnonyms 'Bushman' and 'San'. Acta Academica, 42(1): 168-186.

REAGAN, TG. 2007. Language-in-education policy in South Africa: The challenge of Sign Language. Africa Education Review, 4(2): 26-41.

RICENTO, T. 2006. Language policy: Theory and practice: An introduction. New York: Maiden, Blackwell.

SHOHAMY, E. 2006. Language policy: Hidden agendas and new approaches. London and New York: Routledge.

SPOLSKY, B. 2004. Language Policy. UK: Cambridge University Press.

TOLLEFSON, JW. 2002. Language policies in education: critical issues. Mahwah, NJ: Erlbaum.

THONDHLANA, J. 2000. Contrastive rhetoric in Shona and English argumentative essays. Harare: University of Zimbabwe Publications. 
UNESCO. 1996. Universal Declaration on Linguistic Rights. World conference on Linguistic rights, Barcelona Spain, 9 June 1996. Available online at http://www.unesco.org/cpp/uk/declarations/linguistic.pdf [Accessed 31/10/2014].

UNESCO. 1997. Intergovernmental Conference on Language Policy in Africa. Harare: UNESCO.

VIRIRI, A. 2003. Language planning in Zimbabwe: The conservation and management of indigenous languages as intangible heritage. Available online at http://icomos.org/victoriafalls2003/papers.htm [Accessed on 27/10/2014].

WIMSA. 2001. Penduka declaration on the standardization of $J u$ and Khoe languages. Unpublished report from the Workgroup of Indigenous Minorities of Southern Africa (WIMSA),Windhoek, Penduka Training Centre, 20-22 April.

\section{BIOGRAPHICAL NOTE}

Maxwell Kadenge is a Senior Lecturer in the Department of Linguistics, School of Literature, Language and Media at the University of the Witwatersrand. His research interests fall under the areas of language politics and multilingualism, phonetics, morphosyntax and phonological theory. Email: maxwell.kadenge@,wits.ac.za

Victor Mugari is a Senior Lecturer and Programme Coordinator in the Department of Linguistics of the University of Zimbabwe. His teaching and research interests are in the areas of syntax and its interfaces with morphology, semantics, sociolinguistics and bilingualism. Emails: vicky.mug@gmail.com, mugariv@,arts.uz.ac.zw 